\title{
Role of Holistic Education in Empowering
}

\section{University Students for Industrial Development in Tanzania}

\author{
Sr. Dr. Demetria Gerold Mkulu
}

St Augustine University of Tanzania, Tanzania

\begin{abstract}
The aim of this paper was to explore the role of holistic education in empowering university students for middle economy development in Tanzania. The government has made various attempts to reform its education system to prepare university learners to manage, develop the country for the middle industrialization economy. Holistic education could be a functional tool for empowering youth for industrial Development. The study was guided by three objectives: To determine the contribution of skills taught at the University in empowering the learners for Industrial Development, examine the education system to industrial development, to determine the attitude of university learners towards self-reliance in Tanzania. The survey design was adopted and purposive sampling, stratified, simple random selection method were used to select 150 participants from a population of 2000 students from five universities. Forty lecturers were selected from a population of 500. Five university deans, and 5 university managers were purposive sampled, this made a total of 200 participants. The study utilized mixed methods, convergent parallel research methods designs, which involved quantitative and qualitative research methods. The instruments for data collection were a questionnaire, in-depth interview guide, and observation. Validity and reliability were checked, the result of Cronbach's alpha was 0.861 indicating that the instruments were valid and reliable. Data was collected, coded using expressive statistics with the support package for Social Sciences (SPSS) Version 21. Qualitative information were coded by the naming of conceptual categories and main themes to obtain numerous realities. The results demonstrated that majority of graduates in Tanzania were preparing for white collar's job, they lack capacity to transfer theoretical to work place situation which is needed. The study suggested: Educational Curriculum needs to be reviewed to meet the demand of the people, commence an intensive mentoring programs by formulating link with other industry investors, alumni, professional, and business professions so that university learners can acquire knowledge and skills for industrial development.
\end{abstract}

Keywords-Holistic Education, empowering youth, Industrial, development.

\section{BACKGROUND OF THE STUDY}

The current study explored the role of holistic education in empowering university students for middle industry economy. Young people are energetic conscience of the dynamic globe, vigorous drivers of social change, and harmony in any progressive nation, for this reason, youths ought to be flexible and tolerant enough to be well knowledgeable, equipped and mentored by victorious professionals with adequate learning.
The intention of this study is to explore holistic education in empowering the youth for the national development. The role of holistic education in this study signifies: the kind of instruction which innovates and transforms the whole person physical, mental to become critical thinker. Holistic education could be a functional tool for empowering youth for industrial Development. The Tanzanian government is preparing for middle industry economy by 2025 . This will happen if adoption of Holistic 
education to all level of learning which will transform the youth, as well as the whole society. In the contrary this dream will lead to disastrous outcomes that undercut our well-being, goals and will ultimately devastate our senses of transformative, innovative community and propose addresses many aspects, including the physical, spiritual, and educational knowledge, skills as components of young therefore the youth are paradigms in national management (Fletcher, 2014).

Holistic Education is a technique which focuses on preparing learners to meet any challenges they may face in life and in their academic career. The most crucial theories behind holistic education are learning about oneself, developing health relationships and positive social behaviors. Holistic Education provides information and skills to the youths, as well as influences the personality of the youth of a nation to be critical and productive. However some other writers such as: (Rudge 2008: John, 2017) commended that holistic education should start from the lower level of education and parents and teachers being the first teachers should assist the pupils to learn and recognize how to be able to do what they want in life.

Holistic Education is a model which focuses on preparing youngsters to be able to encounter with any problems they may come across with in life and in their educational occupation. The most important theories behind holistic education are learning about oneself, developing health relationships and positive social behaviors, social and emotional development, resilience, and the ability to view beauty, experience transcendence and truth. Holistic education notes that youth need not only to develop mentally, but also progress in skills as capability to endure in the contemporary world and to transform the world whenever they will be after graduating from their studies.

John (2017) examined on holistic education focusing mainly on principles holistic approach in education in USA. The findings demonstrated that the characteristics of holistic education; nurtures the development of the whole person, It revolves around relationships (egalitarian, open, and democratic relationships), It is concerned with life experiences (instead of "basic skills"), It "recognizes that cultures are created by people and can be changed by people" (instead of conforming and replicating a established culture), it is founded upon a "deep reverence for life and for the unknown (and never fully knowable) source of life
In Nigeria, Kaigama and Audu (2014) looked on holistic education a needful system of education in conflict affected places. The study findings shows that in holistic education, the lecturer is seen less as person of authority who leads and controls but rather is seen as a acquaintance, a adviser, a spur, or an experienced travelling companion. These findings contradicted with the findings of (Hagedoorn, and Mpehongwa, 2013) who asserted that holistic education would create the youth to become the core of a nation.

Youths are crucial tool that would boost the transformation of the national economy. Universities stand at the top of the education system as a place for pursuit and dissemination of information, skills, good behavior, and values. Education is the pillar of national growth (Neamtu, 2014). There is no nation can attain sustainable industrial development without investing heavily in human capital that is the youth (Ankeli, (2019). If Tanzania intends to have industry development it has to start with investment in holistic education which instills the youth with skills, knowledge which can be applied in industry. Holistic education would create the youth to become the core of a nation whose progressive development, vitality, destiny, and well-being are intrinsic in their creative talents and visions of sustainable human survival. Holistic education would enforce the youth to involve in industry development, (Hagedoorn, Gasper Mpehongwa 2013)

According to Ndalichako (2016) pointed out that in the contemporary education system is required to be both effective and efficient, to reach the goals set for them while making the best use of available resources. In addition the study pointed out that economy transformation dependent much on youths. Hence, youngsters are the pillar of the national economy and they play a pivot role in economic production, particularly in the low income countries such as Tanzania. Therefore the current paper focuses on the role played by holistic education in empowering the university students for industry development in Tanzania.

Holistic education is the schooling that focused on molding the whole person by imparting knowledge, skills, changing the learner to become critical thinker, problem solver, and job creator and not job seeker. Holistic Education is the learning which provides knowledge, information, and builds the character of human being of having a set of philosophy and ideals; Holistic education is learning which provides value education which has been 
worldwide apparent as an answer to the challenge of strengthening the moral and social fabric of nations which is missing (UNESCO, 2010). Learners are guided for selfdevelopment and self-reliance so that values become a part of their character, (Ahmad, Krogh, Gjotterud, 2014; Nani, 2019).

In the same line, Almquist, Bailes, Barisa, Cardenas, Collins, Kontos, Okonkwo (2016) Asserted that low income countries including Tanzania should empower university students by equipping the youngster with holistic education which would act as a gateway for industry and self-reliance in national sustainable development. Hence empowering the university students is among the processes of strengthening the youth social, economic, spiritual, political, and capability of individuals to be able to involve in self-reliant and creative, efficiency. Empowering university students by imparting applicable knowledge and skills to build excellent character reinforce decision making and strengthen the value of competent community service. Besides that, Bareke, (2018 asserted that empowering the university learners is a formative mechanism of cheering young people to obtain the relevant skill and orientation to create great things that ensure working towards accomplishing they're personal, educational, and national goals.

In this rapidly changing world, the quest for industry development through education has for all time been a worldwide desire. This factor forces many countries in the world including Tanzania to renovate their educational curriculum and consider investing heavily in the education sector. The National Bureau of Statistics (2014) asserted that 35 percent of the 52 million populations of Tanzanians are youths aged between 15 to 35 years. This implies a huge number of learners graduating every year, and the issue of unemployment is increasing in Tanzania (ILO, 2017).

Various studies have indicated that the status of youth specifically on unemployment issues across the globe is alarming. Even though the same students graduate with "A"s "B"s and high GPA's. Unemployment increases are driven by the slowdown in emerging economies. The challenge of youth unemployment is globally acute for instance in Southern Asia 32.9 rate of unemployment, the Arab States 32.3 percent and African countries including Tanzania, unemployment rates are, respectively, 30.2 percent. In addition recent statistics indicate that the Tanzanian youth unemployment 13.70 percent in 2017 up to the present (ILO, 2018, Ndulu, 2017).

\section{STATEMENT OF THE PROBLEM}

Tanzania has made various attempts to reform its education system to prepare university learners to manage, develop the country for the middle industrialization economy. Various major policies in the interest of schooling have been made such as: Secondary Education Development Programme (SEDP I and II), The Education and Training Policy (1995), Improve quality of Education and increasing access, The Technical Education and Training policy (1996), National Higher Education Policy (1997), Education For All (EFA), Tanzania Development Vision 2025 (URT, 2010). Unfortunately, these efforts have not produced the desired effect. The situation of Tanzanian educational is still appalling. Surprisingly enough some rich Tanzanians prefer to propel their family to study in abroad such as: Rwanda, Burundi and Uganda. It is no longer news that Tanzania is arguably one of the growing countries in Africa, in terms of raw material, major mines and gas producer, this is to mention some. Paradoxically, most Tanzanians live beneath poverty column of one dollar per day. Also, it has been a complaining among Tanzanian Youth on unemployment matter. It is in this regard the study sought to explore the role of holistic education in empowering the youth for industry development in Tanzania

\section{Objectives}

i. To determine the contribution of skills taught at the University level in empowering the students for industry development in Tanzania.

ii. To establish the influence of university courses in empowering university students for industry development in Tanzania.

iii. To determine the attitude of university learners towards industry development in Tanzania.

\section{Significance of the study}

The results and conclusion of this work may provide insight to policymakers in the Ministry of Education on the possibility of renovating the curriculum of education to create effective learning in all system of education

The findings from the current study can be a source of inspiration for other universities to develop similar mechanisms that would help them mount the growing competition between Education in all institutions and industry sectors. 
Finally, the details would also shed some light on what would form other interventions in revitalizing the provision of education without discarding the proven practices that improve the quality of education fostered in these institutions in Tanzania and the world at large.

All in all, the study may contribute to curriculum renovation and practices by illuminating school factors that could compensate for the social disadvantages that hinder the provision of better education from kindergarten to universities in Tanzania

\section{Scope of the study}

This study confined in five universities in Tanzania. The study delimited to the following participants: all academic staff, administrators (such as Deans, Supervisors, and Heads of departments), third year university students and Human Resource Managers. The study focused on role of holistic education in powering university students for industry development. The researcher prefers to use lecturers in this study because they play special role in the process of teaching and learning.

\section{Conceptual Frame work}

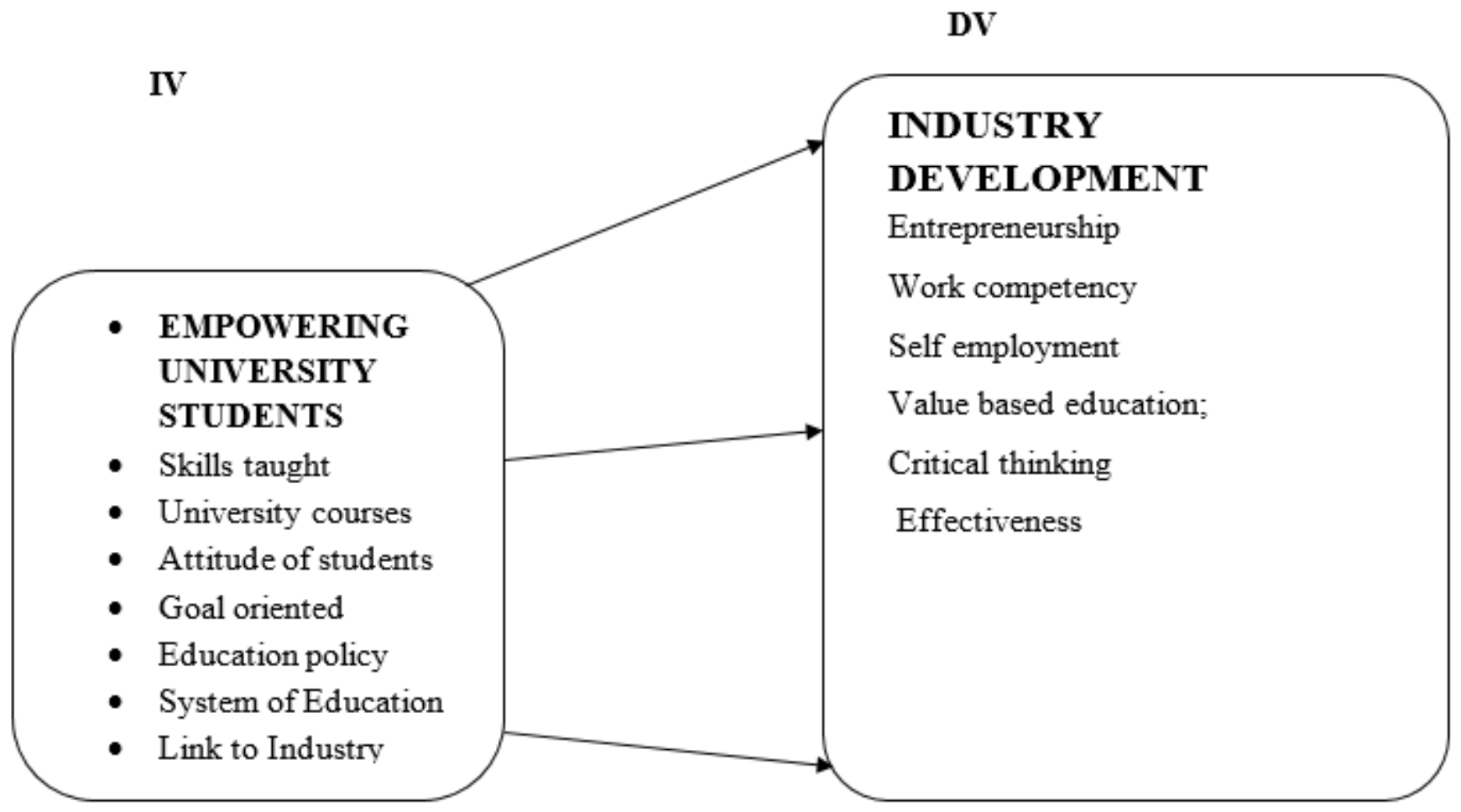

Fig.1: Illustrates Conceptual Framework

Figure one indicates how education and industry development depends so much on the Skills taught to learners from primary to University level. Perception of students and Goal-oriented the whole system of education matters a lot. Holistic education empowers youngsters to have value base, critical thinking, and link to industry final economy development. If we want to transform our economy to middle industry economy we must commence with renovation of our educational system. Youth in all schools, and universities are empowered by providing them with knowledge and skills. Various university courses, appropriate attitudes, education policy, and theoretical learning should link to various industries. Automatically the grandaunts youth will be critical thinkers, they will involve in self employment, Entrepreneurship, work competency, value based education; they will be effectiveness and finally they will involve in industry development. The primary work to do if we intent to have middle industry economy is to provide holistic education to the youth other things will smoothly follow. 


\section{REVIEW OF RELEVANT LITERATURE}

This section reviews what other researchers have done in the field of Holistic education in empowering the youth for industry development. The review included an examination of relevant theory and empirical research studies on the subject.

\section{Jacques' Theory}

Jacques Delor propounded the four pillars of learning. Learning to know, learning to do, learning to live together and learning to be innovative in the sense of holistic education. This implies that education should bring change to individual and society at large. Education should bring positive development of human kind (Smits, 2002).

\section{Learning to learn}

Mastering of the theories includes the progress of the faculties of remembrance, imagination, analysis, being creative, problem solving and the ability to think in a coherent and critical manner. Learning to learn means having the skill to direct and take accountability for one's own learning, for keeping one self up-to-date, for knowing where to look for knowledge. Thus university has the role of provision of theoretical education so that the learners to know theoretically education.

\section{Learning to do}

Holistic Education is expected to produce graduates who are able to pave the way forward with full determination in the world which is changing faster than ever. This implies that the university needs to give chance to the learners to learn education by practical or hands on, as it is said that practice makes perfect. The learner needs to acquire skills from industry, this meant that education should link to industry, learners should learn theory and practical as well so that learners becomes competent, skillful and become productive in professional work.

\section{Learning to live together}

One of the of holistic education role, is to mold the youth to be flexible in the workplace, relating with one another, capable in transforming theoretical into practical, work- creation, and a eagerness to take risks and resolving it. Education should force young grandaunts to the societal role of education and the consequent balancing between knowledge and action sharing, appreciating of diversity. This idea implies that education needs to bring positive change to the learner. The role of education is to mold the learner to be able to live peaceful with everybody in the society.

\section{Learning to be human}

Holistic education assists the youth to be human through acquisition of information, skills and principles conducive to character development in its academic, decent, cultural and physical degree. The educated learners should have values as it is being emphasized by Dewey in 1817 that the role of education is to bring change to the individual. That means the more you are educated the more you need to have values and become better than those not educated. Nevertheless this idea sometimes brings contradiction, you may find out that people who are educated behaves as if they are not acquired education.

United Nations (UN), meet in New York in 2018, asserted that the situation of education across the third world countries including Tanzania is frightening. The report

highlights an alarming reality: That half of all current jobs are expected to disappear by 2030 due to automation (The Association of African Universities, 2012).

\section{Empirical studies}

Alemu (2018) examined on the missing links between the provision of education universities education and industry. The study demonstrated that graduates failed to meet the requirements of the industry because they were neither well equipped nor prepared with both theoretical and practical so as to fit in the world market. Hence the researcher commended that there was a need to change the type of training offered in the university. In the previous study Alemu fail shortly because he neither indicated methodology nor design used in the study. the current study employed the mixed method and five universities were involved in the study.

In relation to the current study, Ibbih and Galya (2014) conducted a study on industrialization and growth in African countries. The study employed a cross-sectional analysis involving 54 African countries to correlate the relationship between industrialization and the growth of the people. The study findings indicated that the structure of an industry in most African countries, except the southern African economies and eastern African economies, was based on mining's and utilities rather than industrialized which more growth was stimulating. In addition to this, the study discovered that industrial development in third world countries has not to transfer effects across member countries 
in Africa. The previous study dealt with analysis on industrialization and growth, failed to indicate the sampling methodology used, while the current study looked on impact of holistic education to empower the youth for industrial development.

\section{Holistic Education}

Holistic Education is a philosophy of learning which provides knowledge, information, and builds the character of the learners by equipping them with a set of values (Sheth, Acharya, Sareen, 2019). Holistic education is a kind of learning which provides value education which has been worldwide apparent as an answer to the challenges of strengthening the moral and social fabric of nations (Horne, Khatiwada, Kuhn, (2016). World Learners are guided for self-development, self-reliance so that values become a part of their character. Holistic education is generally designed to bring about industrial development which in turn is a key player in economic development.

This must have made Robinson (2012) define holistic education as a systematic application of scientific and other organized knowledge to practical tasks (pg. 54). Rarely is there any human effort without application of technology to simplify the task at hand either through the application of technical information or the use of technological devices or machinery and apparatuses. Technology, therefore, encompasses scientific knowledge that must be possessed by man. The reason is that its equipment, devices, and apparatus are quite beneficiary to man. For instance, the uses of electro-mechanical devices, sophisticated gadgetries, and computerized equipment have made life easier and comfortable

International Labour Conference (ILO) (2012) reported that 621 million young people aged 15-24 years old are not in education, employment or training. Global 75 million young people were trained but have no job. In the next decade, one billion young people would enter the workplace and large numbers of young people face a future of irregular and informal employment. Almost 90 percent of all unemployed young people live in developing countries. The report demonstrated that the proportions of worldwide unemployment are steadily increasing and that the number of those without jobs remained at an all-time high of more than 195 million. joblessness is a global issue, but it occurs mostly in developing countries, including Tanzania. Therefore massive youth unemployment in any country is an indication of far more complex problems. Recently, unemployment has knocked the Tanzania youths heavily. Also, the report estimated that 23 percent of young people currently employed in the world are earning less than one dollar.

In Tanzania, Ndalichako, (2016) conducted a study on economic development. The findings demonstrated that the government is challenged in various ways including lack of provision of quality and efficient education. Hence innovation of training institutions is highly recommended so as to match with the necessities of current technology, and quality of education delivered. In addition, there was an urgent need to re-balance both the number and relevant skills at all levels of education.

In relation to this study, Association of African Universities (AAU), (2012) reported that strengthening university industry linkages in Africa is very crucial. Industry linkage can be formal or informal link. However most of African universities have been criticized that graduates fail to transmit skills, to workplace, their research are irrelevant to the needs of employers and society at large. Moreover the AAU asserted that university learners should surpass knowledge and skills. In addition learners should link to workplace and involve heavily in research capacities, curriculum development and consultancy

In the same streak Noe, and Kodwani, (2018). commended that the university should respond quickly to industry needs. Besides, learners should link to workplace so as to attract individuals looking for employment, also create a center of attention for corporations looking for professional progress for their employees. Higher learning managers stated that universities must work more closely with industry to learn the needs and acquire skills needed in the industry.

Notwithstanding, Okoro, and Ezeonwumelu (2019) asserted that entrepreneurship education has globally an effective and practical tool of successful and realistic for industrial development, job creator, and prosperity creation (Correa, Zuñiga, 2014) highly praised that Entrepreneurship education is an aspect of enhancing an individual and creates in the learners' attitude to assume the jeopardy of venuring into something new by applying knowledge and skills learned in university. Entrepreneurship education was taught to stimulate creativity in students, enable them to identify opportunities for innovation and motivate them to transform the ideas into 
practical and targeted activities whether in a social, cultural or economic context.

In the same line Okoro and Ezeonwumelu, (2019) agrees that entrepreneurship education would provide opportunities for students to access their attitude, aptitude, and skills relating to those necessary for developing and running business. Entrepreneurship education entails teaching learners to become businesspeople, the essential skills required to build viable enterprises, equipping the trainees with skills needed for taking responsibility and developing initiatives of prospective trainees. The previous studies were conducted long time ago, hence there is time gap, thus the current study views the role of holistic education in empowering the youths for industry development, and wants to find out if what was found by Okorofor, Okereke, and Ezeani will be similar to the current study or not.

Unemployed are people able, available and willing to work at the going wage rate but cannot find a job despite an active search for work (Blustein, Connors-Kellgren, Olle, and Diamonti, 2017). It also means scare human resources are being used to produce goods and services to meet people's needs and wants (Blustein, Connors-Kellgren, Olle, and Diamonti, 2017). Unemployment or joblessness occurs when people are without work and actively looking for work. Unemployment or joblessness occurs when people are without work and actively looking for a job but is unable (International Labour Conference, 2012).

\section{Summary and Knowledge Gap}

Most of the reviewed literature indicates that Education plays a pivotal role in national development. African countries including Tanzania Education at all levels seriously need renovation. Holistic education is one of the effective measure to empower the youth for national development in sub Saharan countries including Tanzania.

Most of the reviewed literature focusing on developing countries, particularly in Sub-Saharan Africa is generally less visible or not much documented. This paper sought to fill this gap. More specifically, the paper addresses the role of holistic education in empowering university students for education and industry development.

(Allawadi, 2010).
IV.

RESEARCH DESIGN AND METHODOLOGY Introduction

This section presents the research design, target population, sample size and sampling procedures used in the current study. It also describes the research instruments, namely questionnaires, interview guides, and observation. The procedures of determining the validity and consistency or trustworthiness of the instruments are discussed, as well as the procedures for data collection and analysis, and ethical considerations underpinning the study.

\section{Research Designs}

This paper adopted mixed method research designs (MMRD) cross sectional survey specifically convergent parallel where the researcher collects quantities and qualitative data simultaneously then analyzes separately and merged at the end of the stud. This fact supported by Creswell (2014). In this study, a qualitative research method was preferred because it provided detailed data about human behavior and emotion, something that the quantitative approach may not achieve. Phenomenology design, according to (Joarder \& Yazam, 2013) allowed the researcher to hear the concern of the interviewee when they responded to the open-ended research questions. The researcher exploited the strengths of the cross-sectional survey to collect complementary data that we're reducible to meaningful inferable numbers.

\section{Target Population}

The current study was confined in the role of holistic education for empowering the youth as innovation for development Tanzania. The population of the study comprised of all academic staff, university managers and third-year university students This population is considered adequate to provide key information pertinent to the objectives of the study. The researcher preferred to use lecturers in this study because they had experience with the academic staff transit from one university to another. Hence, they provided relevant data. University administrators such as deans and heads of departments were involved in the study because by their positions, they were influential in recruiting, motivating and inducting lecturers. They also supervised curriculum implementation and were in a position to provide information on what happens in their respective universities. Third-year students were included in the study because they had been in the universities for long and were thus aware of the issue of academic staff attrition. 
Also, students at this level of education know the effects of lecturer attrition on education.

\section{Sample Size and Sampling Procedures}

Both probability and non-probability techniques were employed. In probability sampling, there was a random selection of participants for the study and each respondent in the population had an equal likelihood to be chosen in the sample (Ahuja \& Kumar, 2012 and Phrasisombath, 2012) in the current study the researcher sampled students by using stratified sampling technique based on gender followed by simple random sampling to select 75 male participants and 75 female participants giving the total of 150 respondents. Forty lecturers were selected using simple random sampling while purposive sampling was adapted to seleced 5 university deans, and 5 university managers giving a grand total of 200 sample size. These participants were enough to generate information for the study. The study utilized mixed methods, convergent parallel research methods designs

\section{Data Collections Procedures}

The data were obtained through questionnaires and in-depth interview guide. The questionnaire instrument was divided into five sections comprises both open and closedended questions sought information on the role of holistic education in empowering university students for selfreliance. These instruments were enough to collect the needed information.

\section{FINDINGS}

Question one sought explore the contribution of knowledge, skills taught at the University in empowering the students for industry development.

From the major findings, it revealed that 78.0 percent of the participants commended that today's education in Tanzania is Examinations oriented, learners are valued if they acquire "A"s and High GPA's hence, lecturers are busy teaching learners how to answer exams and we have proved that majority of the schools in Tanzania are performing well in examinations and the same students do not excel in industrial when given job. This relates that African universities including Tanzanian Universities have often been criticized as ivory towers that toss out graduates and research that are immaterial to the wants of the employers and the community, economic and mechanical limitations encountered by the third world countries economies. This finding is similar to Khan and Anwar, (2013, p. 270) who lamented that "universities and higher learning institutions are producing degree holders with inadequate training skills for the global".

One of the interviewees claimed that:

If I could get another chance to go to the university to study the same thing I could acquire more skills, but in the meantime, my education qualification and skill level do not relate to the world market hence, there are not related I could not do anything if I am given the real job to perform (interviewee no four, August 20, 2019).

This implies that graduate completes their studies without gaining more skills. Youth admire for the second chance to go for training. Youngsters believe that they could achieve skills if they are taught the same thing twice which might not be the same. Nevertheless, Tanzania is blessed with a lot of natural resources especially mineral and agricultural resources, and a large workforce.

In addition, the current study also demonstrated that most of the grandaunts 78.0 percent lack capacity to transfer theoretical knowledge to real situation which is needed to industry. There is a growing observation that the comprehension and skills obtained by students in universities in Tanzania might not meet the requirements of industry and the wider economy. University learners lack link to industry while studying at college and university levels, the nature of the labor market is that many young people lack the necessary skills and instruction to impress employers.

\section{Communication}

Language variation from standard one to standard seven and abruptly change to a foreign language that is the English language in form one to form four which sharks many learners in Tanzania. Unemployment challenge in Tanzania will not end by itself until we change the root that is curriculum renovation to fit the need of the people, this is due to the detail that: The training that students receive at many African universities including Tanzania do not train university learners sufficiently to meet the necessities of industry and the job market. This disparity between what students learn and what industry needs - fixed with undertraining in the critical skills of problem-solving, analytical 
thinking and communication - is blamed, at least in part, for

employment many African countries are witnessing.

the emerging high graduate unemployment and under-

Table.2: Role of University in preparation for industrialization Economy $(n=100)$

Students

lecturers

\begin{tabular}{lcccc}
\cline { 2 - 5 } Item & Yes & Not sure & Yes & Not sure \\
University produce research & $13(8.6)$ & $87(58.0)$ & $14(28.0)$ & $36(72.0)$ \\
University produces innovation for industry & $34(22.6)$ & $66(44)$ & $15(30.0)$ & $35(70.0)$ \\
University students are linked to industry & $20(13.3)$ & $80(53)$ & $20(40.0)$ & $30(70.0)$ \\
University provides expertise for industry & $5(3.3)$ & $95(63)$ & $12(24.0)$ & $38(76.0)$ \\
University is a market place produce & & & & \\
and sell goods & $10(6.6)$ & $90(60)$ & $4(8.0)$ & $46(92.0)$ \\
& & & & \\
\hline
\end{tabular}

Table 2 demonstrated that 8.6 percent of respondent asserted that the university produces research. In addition 58.0 percent of the participants hesitated to agree with the question that research is being done in the universities or not. This indicated that only a limited number of learners do research and published but majorities of them do research for the sake of doing. The same response is cited by the lectures:

To empower youth, the Tanzanian government should provide conducive environment and all the necessary equipment and materials for easy teaching and learning which should link to industry so as to enhance the youngsters to acquire knowledge and skills and be able to have self employment after graduating.

In the same line one of the participants claimed:

Universities should work closely with consultation with industry, business people, alumni, and other professionals before increasing courses for specific industry disciplines. Colleges, universities should collaborate with industries to offer a core curriculum that will create the learners more valuable to workplace (Interviewee E, 1 8. 9. 2019).

The study demonstrated that there is relationship between role of holistic education in empowering the youth and industry development. Industrial education need to be inculcated into the school curriculum to endorse learners. It is a means of plummeting unemployment since it is skilled oriented and employee motivation. Therefore, all school programs should be geared toward providing industrial and entrepreneurial skills One of the interviewees asserted that: As the world changes, we need to continue to educate our employees, so as it relates to technology. The question is whether university around can keep up with the industry.

One of the interviewees asserted that:

Institutions need close consultation with business

before mounting specific courses for specific industry disciplines. Institutions need to offer classes more closely tailored to the real world.

Universities should partner with industries to offer a curriculum that will make the students more valuable to companies (interviewee E, 18. 9. 2019).

This quotation concurs with; Kuper (2012) claimed that universities' education needs to form closer bonds with industries and businesses to succeed in the corporate training market by ensuring that programming on offer lines up with what is needed by potential customers. This implies that skills do not depend on a person's essential inherent ability but must developed, empowered through preparation practical and experience.

If the objective of holistic education is to furnish individuals with industrial skills, which are pertinent straight to work, then the best method is industrial training hands on that would provide education and training that enable individuals to involve directly in the hands on or 
practical. The practical system is one of the objectives of holistic educations it enhances the individuals to act as entrepreneurs, self-employment, is one of the strategies to facilitate experiments by facilitating first hand information in a controlled environment this idea is in line with (Kuper,
2012) who claimed that university should respond quickly to industry needs.

The participants were asked various questions on curriculum implementations the following were the answers as indicated in table 5

Table.3: Curriculum implementation $(n=200)$

\begin{tabular}{lcc} 
Item & Frequency & Percent \\
\hline Technology link to education & 60 & 30 \\
Lecturers in University teaching styles & 8 & 4.0 \\
e-learning, e-journal, e-books & 10 & 5.0 \\
The curriculum employed in university & 04 & 2.0 \\
System of education from P-U & 30 & 15 \\
Youth are joblessness & 64 & 32 \\
Teaching link to industry & 10 & 5.0 \\
Parent involvement & 14 & 7.0 \\
Total & $\mathbf{2 0 0}$ & $\mathbf{1 0 0}$ \\
\hline
\end{tabular}

The findings from table 3 indicated 30 percent of participants responded that Education should link to industry. This implies that Education is vital to industry development. No industrial development is possible without holistic education. A fair education system promotes not only economic development, but productivity, and generates individual income per capita. Besides this, Universities and industries should work together concurrently to push the boundaries of knowledge, they turn out to be a powerful guide for innovation and socio-economic development of industry development. Nevertheless, the system of education in Tanzania does not relate to the educational goals which are self-employed. Tanzanian education from kindergarten to university is Examination oriented; students graduate with "A's" but fail to transmit skills to the real world. Higher learning management should bring together universities with productive sector representatives to revise and improve the curriculum to ensure that students graduate with relevant skills for the workforce.

\section{Third Question University Learners' Perception's Towards Industry Development}

It was important to find out university Learners' Perception's towards industry Development in Tanzania. A research objective emanating from the origin research problem indicates as in figure 2 


\section{Percent}

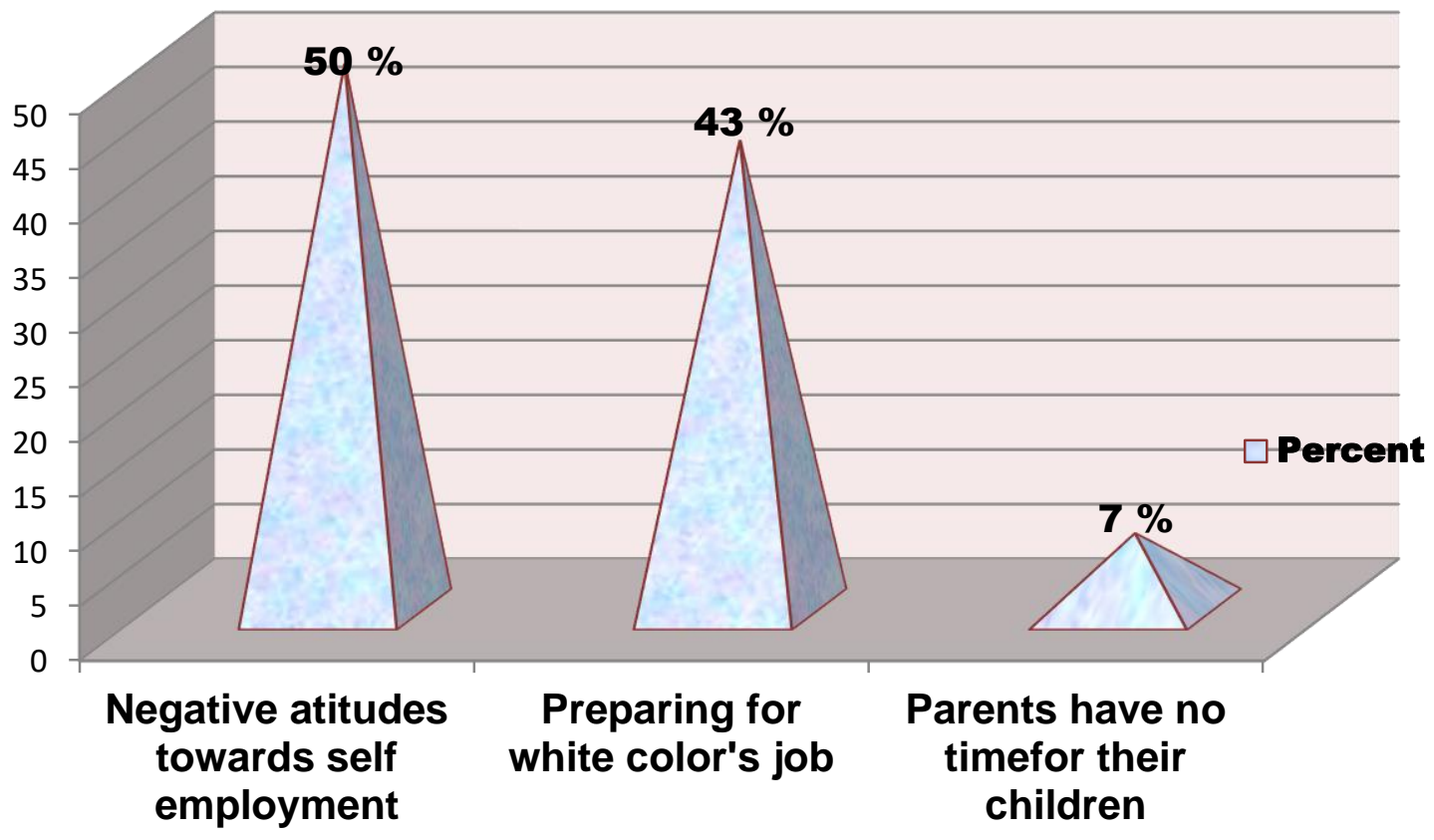

Fig.2: Students' and Parents Perceptions

Figure two shows learner's perception towards industry development in Tanzania. This was important as it was meant to determine whether university learners had negative or positive view on industry and self employment. On the other hand, majority of the students 50.0 percent had negative attitude towards industry development, and self reliance. Most of learners 43.0 percent were preparing for white collar job, they wanted to be employed by the government which could pay them well. However, 7.0 percent of parents had no time to mentor their children while they are in schools. Parents' attitude towards university education is to have return, soon after graduation. Parents should participate fully in upbringing their children even when they are in the university level.

In order to make university education functional, relevant and practical, the Tanzanian government, through Tanzania Commission of Universities (TCU) should include all subjects to industrial link programme. This implies that university learners should be taught theories and practical knowledge which links the learner to industry while studying. The study findings revealed that Entrepreneurship subject is not compulsory. Most of the universities in Tanzania have set freedom to those students who want to study entrepreneurship. Nevertheless the current study recommend that entrepreneurship subject should be compulsory course for all students in higher learning institutions in Tanzania. The aim of this policy is to ginger in the student's industrial spirit that will help to curb the increasing rate of graduate unemployment. This will help graduates to recognize business opportunities, mobilize resources and exploit the opportunity for self- employment which will be beneficial for community and national development. This study also revealed that holistic education increases the employment level of the country, job creativity, productivity, intensifies competition and makes considerable change for living standards.

\section{SUMMARY}

Curriculum should be reviewed to meet the demand of Tanzanian people. 
Besides that, all stakeholders should involve in curriculum renovation such as: curriculum Implementers, parents, university learners and others. All teaching should link to industry. Lecturers in University should adopt new styles of teaching; such technique: E-learning, e-journal, and others.

University management should introduce an intensive mentoring programs by building alliances with other entrepreneurs, industries, business professionals, alumni, and investors, so that students can be empowered. Universities in Tanzania should package programmes that are capable of meeting the employment opportunities for the teeming number of graduates and all programs should link to industry development.

Lecturers were positive in their perception towards education-link to industrial.

\section{Communication}

Language variation from standard one to standard seven and change to a foreign language that is the English language, inform one to form four which sharks many learners in Tanzania. English language should not be seen as colonial language but a language for interaction, language which links one national to the other nation. The reasons for youth unemployment are fairly similar to other causes of unemployment. Deficient in qualifications, lack of a link to the industry while at college and university level, the nature of the labor market is that many young people lack the necessary skills and training to impress employers.

\section{Youth Joblessness and Skills Disparity}

From the finding, the study demonstrated that the joblessness issue is frightening. The number of graduates in Tanzania is increasing day after day however graduates are looking for a job they don't get although they have all the qualifications. The curriculum employed in the universities. From the findings, it was revealed that 98 percent of the participants responded that policymakers do not involve policy implementers in preparation and innovation of the curriculum as policy.

The study indicated that 89 percent of the participants asserted that policymakers presume that curriculum execution is a process that translates straight into classroom reality. The contribution of lecturers, university students, parents play a pivotal role in curriculum innovation hence, parents should mentor their children while schooling in all levels. Lecturer's attitudes, feelings, and perceptions should not be devalued before the launching of any innovation.
Again there is a gap between what is taught in schools and universities and the skills currently needed by the job market.

\section{New Teaching Styles}

The findings have revealed that if Tanzania intends to be effective in industrial development it should familiarize with the fast advancing technology in provision of quality education. Tanzania should adopt e-learning, e-teaching, ejournals, e-books, mechanisms which becoming increasingly available online and vial mobile, conventional teaching must adapt to remain relevant and benefits of elearning. If we are focusing for middle industry economy we should be lead for a change and adopting new technologies Lecturers in universities, should also be up-todate to support and evaluate the learners in new technology, authentic tasks that nearly always related to a real external client or assessor. This finding concurred with Almquist, Bailes, Barisa, Cardenas, Collins, Kontos, Okonkwo (2016)

Change is inevitable whether we like or not hence we should plan for the positive change. Technologies are predicted to have a noteworthy effect on industry development it enhances the progress of national economy. If we are focusing for middle industry economy we should be equipped for a change and adopting new technologies. Provision of education should be students' centered learning.

\section{Lecturers in Universities}

Lecturers should be up-to-date in the provision of teaching by adopting advanced technologies so as to evaluate the learners in new, authentic tasks that nearly always are related to a real external client or assessor. Moreover the provision of education should be students' centered learning. In addition senior $\mathrm{PhD}$ lecturers by desirable quality of their level of education are accountable and responsible for research supervision and holding senior administration positions. The result indicated that senior lecturers were inadequate almost in all universities in Tanzania. This implies that the role of holistic education cannot be empowered well to learners in the university if lecturers are inadequate.

\section{Parents' involvement}

Parents should be responsible for the growth of the education of their children. There is a strong feeling that in the present times there is a calamity in character formation. It is also felt that since the character is largely molded 
during childhood and youth, it is the duty of parents, educational institutions, lecturers to offer knowledge for personality building need to have time to sit with the youth and monitor, by give directions to good behavior (Munir, and Aftab, 2012)

\section{CONCLUSION}

Education is vital to industry development. No industrial progress is probable devoid of holistic education. A fair education system promotes not only economic development, but productivity, and generates individual income per capita.

Graduates' in Tanzania should be prepared for knowledge, skills which are transferable to the workplace moreover educational curriculum needs to be reviewed to meet the demand of the people, commence an intensive mentoring programs by formulating link with other industry investors, alumni, professional, and business professions so that university learners can acquire knowledge and skills for industrial development.

\section{Recommendation For Action}

There is vital requirement for a workable educational policy for Tanzania. It is for this reason that the following recommendations are advanced. Education should be removed from the sphere of politics. It should be made purely as Institutional matter. The Tanzanian government leaders should develop the necessary political good will for education to grow.

University management should introduce an intensive mentoring programs by building alliances with other entrepreneurs, industrial, business professionals, alumni, and investors, so that university students can be empowered.

Curriculum should be reformed to convene the demand of quality education in the country. This review should involve all stockholders; such as curriculum Implementers, parents, university learners and others. All kind of teaching should link to industry also lecturers in University should adopt new styles of teaching.

The Tanzanian government should start with improving higher education with good and quality research centers. The World Bank should build capacity on a country that holds its expectations in its hands such as Tanzania. World Bank and other donors should make sure that African countries can build their future.
Government stakeholders specifically Tanzania Commission of Universities (TCU) need to commence intensive mentoring programs by formulating links with other industries, entrepreneurs, alumni, investors, and business professionals so that university students can be empowered and fully involved in self-reliant.

\section{REFERENCES}

[1] Ahmad, K. A., Krogh, E. , Gjotterud, M.S. (2014). Reconsidering the philosophy of Education for Self-Reliance (ESR) from an experiential learning perspective in contemporary education in Tanzania. Educational research for social change (ERSC) 3(1) 3-19

[2] Aftab, M.. and Munir, S. (2012). Value Education towards empowering the youth. International Journal 2(12), 22832290

[3] Allawadi, S. C. (2010). Entrepreneurship challenges in 21st century. Indian Institute of Materials Management, Mumbai.

[4] Alemu, M., Yilma, E. (2018). Determinants of Universityindustry linkage: evidence from Dire European Journal of Business and management Dawa City, Ethiopia. 10(13) 5677

[5] Ankeli, G. O. (2019). Acquisition of Entrepreneurial and Scientific Skills for Youth Self-Sustainability and Job Creation towards National Development in Nigeria. World Journal of Entrepreneurial Development Studies, 3(1), 2431.

[6] Association of African Universities (AAU) .(2012). Strengthening university-industry linkages in Africa: A study on institutional capacities and gaps.

[7] Blustein, D. L., Connors-Kellgren, A., Olle, C., \& Diamonti, A. J. (2017). Promising career and workforce development programs and services in supporting the needs of unemployed populations. In The Handbook of Career and Workforce Development (pp. 105-131). Routledge.

[8] Collins, M. W., Kontos, A. P., Okonkwo, D. O., Almquist, J., Bailes, J., Barisa, M., and Cardenas, J. (2016). Statements of agreement from the targeted evaluation and active management (TEAM) approaches to treating concussion meeting held in Pittsburgh, October 15-16, 2015. Neurosurgery,79(6), 912-929.

[9] Correa, P., and P. Zuñiga. (2014). Public Policies to Foster Knowledge Transfer from Public Research Organizations. Innovation, Technology, and Entrepreneurship Global Practice, Public Policy Brief, World Bank, Washington DC.

[10] Fletcher, A. (2014) A Short Guide to Holistic Youth Development. Olympia, WA: The Freechild Project.

[11] Hagedoorn, Gasper Mpehongwa., (2013). Academiaindustry-government Linkages in Tanzania: trends, 
challenges, and prospects; Journal of Educational Research and Reviews. 8(21) 2093- 2100

[12] Ibbih J. and Galya B. (2013) Cross-sectional analysis of industrialization and growth in Africa. International Research Journals 2 (6) 150-167.

[13] International Labour Conference (2012) unemployment Crisis: Time For accomplishment, as found on http://www.ilo.org/wcmsp5/groups/public/-ed_norm/-relconf/ documents/meeting document/wcms

[14] John, P. J. (2017). Examined on principles followed in holistic approach in education. USA. International journal of research in social science 7(4) 346-353

[15] Kaigama, D. M. Audu H. (2014) Holistic Education: A Needful System of Education for Learners in Conflict places. Journal of Research \& Method in Education (IOSRJRME) 4(4) 23-28

[16] Kuper, S. and Szymanski, S. (2012) Industry relevance and its role of learners.The evolution a destiny solutions Philadelphia nation books

[17] Rudge T. L.(2008). Holistic education an analysis of its pedagogical. The Ohio State university.

[18] Muma, P. C.(2018). Tradition and education for all among the baila people of namwala in Southern Province, Zambia.

[19] Munir, S., \& Aftab, M. (2012). Contribution knowledge towards human progress in India: Theoretical concepts. International Journal of Asian Social Science, 2(12), 2283 2290.

[20] Nafukho, M. F. (2004). Human capital theory: Implications for human resource development. Taylor \& Francis 7(4) 545-551 Ndalichako, J. L. (2016). Report on Industrial development in Tanzania

[21] Neamțu, D. M., Ciobanu, O. G. (2015). Correlations between human development and economic growth. Economy Series Annals of the Constantin Brâncuşi" University of Târgu Jiu. 1(1) 118-122.

[22] Newman, C., Page, J. Shimeles, A., Soderborm, M.. \& Trap, F. (Eds.). (2016). Manufacturing transformation: comparative studies of industrial development in Africa and emerging Asia. Oxford University Press

[23] Munir, S., \& Aftab, M. (2012). Contribution of value education towards human development in India: Theoretical concepts. International Journal of Asian Social Science, 2(12), 2283-2290.

[24] Ngosa, P. (2012). The missing links between teachers training in a technical vocation Education and training and industry in Zambia.

[25] Ndulu, B. J. Ibadawi, I. A., and Ndung'u, N. S. (2017). Macroeconomic performance in Sub-Saharan Africa in a comparative setting. In Comparative Development Experiences of Sub-Saharan Africa and East Asia (pp. 93132). Routledge
[26] Nafukho, F., Amutabi, M. N., \& Otunga, R. N. (2005). Foundations of adult education in Africa. Pearson South Africa.

[27] Nani, G. V. (2019). Entrepreneurship Intervention: Towards Transforming Education in Institutions of Higher Learning: A Case of One Public University Zimbabwe

[28] Noe, R. A., \& Kodwani, A. D. (2018). Employee Training and Development, $7 e$. McGraw-Hill Education

[29] Okoro, C., \& Ezeonwumelu, V. U. (2019). Motivating Students for Entrepreneurial Education in Nigerian Primary Schools: The 'Catching Them Young Phenomenon'. Equatorial Journal of Education and Curriculum Studies, 3(1), 28-36

[30] Okonkwo, D. O., Almquist, J., Bailes, J., Barisa, M.., \& Cardenas, J. (2016). Targeted evaluation and active management (TEAM) approaches to treating meeting held in Pittsburgh, Neurosurgery, 79(6), 912-929.

[31] The United Republic of Tanzania Ministry of Education and Vocational Training (URT) (2010-2015) Dar Es Salaam

[32] Urowoli, C. (2016). Influence of Youth Unemployment on Crime Rate in Lagos Island Local Government Area of Lagos State, Nigeria. Review of Public Administration and Management, 400(4289), 1-11.

[33] Yusuf, S. (2007). In How Universities promote economic growth. Washington DC. World Bank ttp://demo.netcommlabs.com/innovationgrid/pdf/How_Univ ersities.pdf

[34] Sheth, B. P., Acharya, S. R., \& Sareen, S. B. (2019). Policy implications for the improvement of technology transfer and commercialization process in the Indian context. Journal of Science and Technology Policy Management 10(1), 214-233

[35] Smitsa, R. (2002). Innovation studies in the $21^{\text {st }}$ century;: Questions from a user's perspective. Technological forecasting and social change, 69(9), 861-883 